\title{
Regional Climate Impacts of Future Changes in the Mid-Latitude Atmospheric Circulation: a Storyline View
}

\author{
Giuseppe Zappa ${ }^{1}$ \\ Published online: 28 November 2019 \\ (C) The Author(s) 2019
}

\begin{abstract}
Purpose of Review Atmospheric circulation exerts a strong control on regional climate and extremes. However, projections of future circulation change remain uncertain, thus affecting the assessment of regional climate change. The purpose of this review is to describe some key cases where regional precipitation and windiness strongly depend on the mid-latitude atmospheric circulation response to warming, and summarise this into alternative plausible storylines of regional climate change.

Recent Findings Recent research has enabled to better quantify the importance of dynamical aspects of climate change in shaping regional climate. The cold season precipitation response in Mediterranean-like regions is identified as one of the most susceptible impact-relevant aspects of regional climate driven by mid-latitude circulation changes. A circulation-forced drying might already be emerging in the actual Mediterranean, Chile and southwestern Australia. Increasing evidence indicates that distinct regional changes in atmospheric circulation and European windiness might unfold depending on the interplay of different climate drivers, such as surface warming patterns, sea ice loss and stratospheric changes.

Summary The multi-model mean circulation response to warming tends to show washed-out signals due to the lack of robustness in the model projections, with implications for regional changes. To better communicate the information contained within these projections, it is useful to discuss regional climate change conditionally on alternative plausible storylines of atmospheric circulation change. As progress continues in understanding the factors driving the response of circulation to global warming, developing such storylines will provide end-to-end and physically self-consistent descriptions of plausible future unfoldings of regional climate change.
\end{abstract}

Keywords Regional climate change $\cdot$ Atmospheric circulation $\cdot$ CMIP5 $\cdot$ Mediterranean climates $\cdot$ Storylines $\cdot$ Precipitation projections

\section{Introduction}

In the last decade, consensus has started to grow on how atmospheric circulation will respond to global warming [1]. On average, climate projections from multi-model ensembles indicate an overall poleward shift of the mid-latitude westerlies [2], associated with a poleward expansion of the

This article belongs to the Topical Collection on Mid-latitude Processes and Climate Change

Giuseppe Zappa

g.zappa@isac.cnr.it

1 Istituto di Scienze dell'Atmosfera e del Clima, Consiglio Nazionale Delle Ricerche (ISAC-CNR), Bologna, Italy
Hadley circulation [3], and a reduction in the number of extratropical cyclones $[4,5]$. Changes consistent with the models' projections are starting to be observed in the real world, but due to the large year-to-year internal variability in the climate system, not even the observed trends in the zonalmean aspects of atmospheric circulation have yet been unequivocally attributed to warming [6]. Nonetheless, if greenhouse gas emissions are not mitigated and climate model projections are realised, future changes in the atmospheric circulation will not pass unobserved. In the mid-latitudes, atmospheric circulation determines the trajectory of weather systems and their associated precipitation and wind speed extremes [7]; it stirs the transport of moisture from dry to wet regions [8]; it drives hot extremes in summer and cold extremes in winter through the establishment of persistent 
anticyclones [9]. As such, atmospheric circulation change can have a diverse range of societal impacts.

Despite its potential to drive climate impacts, projections of circulation change have not yet translated into high-confidence statements on regional climate change [10]. This lack of confidence depends on multiple causes. Zonal-mean aspects of circulation change, such as the Hadley cell expansion, are not sufficient to constrain the response of regional climate over land [11, 12]. At the regional and seasonal scale, the uncertainty in how atmospheric circulation responds to warming remains large, to the extent that different models can even show opposite forced responses [13]. It would be tempting to treat these uncertainties probabilistically and to take the multi-model mean as a best projection, but such an approach is not supported on firm theoretical grounds [14]. While the multi-model mean usually outperforms individual models in global metrics of climate, this is not typically the case for regional aspects of atmospheric circulation, which can be better represented in some individual climate models than in the multi-model mean [15]. Different features of regional circulation change tend to be averaged out, leading to an overly smooth and possibly too weak signal.

Given this uncertainty in the response of regional climate to global warming, the development of storylines, or narratives, of climate change has been proposed as an informative way to characterise and communicate future climate projections to stakeholders and policy makers [16, -17]. The concept of storyline involves a possible and physically self-consistent future unfolding of global and regional climate events. In a storyline approach, multiple storylines are identified in order to span the uncertainty in the future projections from multi-model ensembles. However, the focus is not placed on attributing a probability to the different storylines but on understanding the driving physical factors, the chain of mechanisms involved and the implications at the regional level.

This report aims to review the future impacts that might unfold from atmospheric circulation change. Thinking in terms of storylines therefore becomes particularly useful and it naturally leads to frame the problem in terms of the following question: what additional information could be gained at the regional level if the response in the large-scale atmospheric circulation were known? After reviewing some methodological aspects ("How to Identify Regional Impacts of Mid-latitude Circulation Change"), this question will be discussed for a selection of regional climate impacts associated with changes in precipitation ("Impacts of Circulation Change on Regional Hydro-Climate") and windiness ("Impacts on Windiness: the European Case"). For each case, different relevant storylines of atmospheric circulation change will be analysed by drawing on published literature.

\section{How to Identify Regional Impacts of Mid-latitude Circulation Change}

Developing physically self-consistent storylines of atmospheric circulation change relies on having a causal understanding of the chain of mechanisms involved. Achieving this understanding requires tackling two separate problems. At a global level, the challenge lies in understanding what climate aspects, e.g. sea surface temperature patterns and sea ice, drive the uncertainty in the regional response of atmospheric circulation. Identifying such drivers ultimately requires numerical experimentation $[\bullet 18]$. Furthermore, at the regional level, an additional challenge lies in understanding the impacts of the response of atmospheric circulation for regional climate change. This requires separating the other aspects of regional climate change that directly result from energy imbalance and surface warming, often called thermodynamic aspects [19]. A clean separation is generally not possible. The different methods either attempt to directly quantify the regional changes due to circulation, or, conversely, to quantify the thermodynamic response expected for no change in circulation, and then define the dynamical part as a residual. Some of these approaches are now discussed.

\section{Internal Variability Analogs}

The response of atmospheric circulation to global warming can resemble, or even project on, present-day modes of internal atmospheric variability [20]. In this case, the impacts that future changes in the atmospheric circulation might have on the regional climate can be directly estimated by identifying analogs of the projected circulation change in the present-day observational record. By referring back to the present-day climate, any thermodynamic influence is by construction excluded.

This approach has been implemented in several ways. The most direct technique relies on linearly regressing the circulation response on the dominant modes of variability in the atmospheric circulation, such as obtained via EOF analysis [21-23]. Alternatively, the linearity assumption can be relaxed by describing the circulation response as a change in the frequency of occurrence of present-day weather regimes obtained by clustering algorithms such as k-means or self-organising maps [9, 24-27]. A limit of these approaches is that accurate present-day analogs may not always be available. For example, in the Mediterranean area in winter, the response of atmospheric circulation to greenhouse forcing does not project on individual present-day modes of internal atmospheric variability [23, 28]. Using clustering algorithms does not necessarily address this issue, as global warming can force a 
change in the structure of weather regimes between the present and the future climate simulations [26, 29]. In these cases, variability analogs might only isolate part of the signal associated with future circulation changes. Additional, more flexible, strategies have shown potential to address these issues. The "constructed circulation ana$\log$ " technique aims to optimally reproduce the circulation response pattern through linear combinations of several analogs extracted from large ensembles of climate simulations or atmospheric reanalyses $[\bullet 30,31]$. Moreover, techniques based on partial least squares regression are effective at identifying the atmospheric circulation patterns that exert the largest impacts on a climate aspect of interest [32]. These approaches have shown good skill at capturing the influence of circulation variability and change on surface temperature, and some promising results are emerging for precipitation $[33, \bullet 34]$.

\section{Budget Equations}

A useful complementary approach to internal variability analogs consists in the inspection of atmospheric budget equations. Two most notable applications have been the use of the moisture budget [35] and of the energy budget [36] to understand variability and change in regional hydro-climate.

The moisture budget equation directly informs on the change in the balance between precipitation and evaporation (P-E) as, in steady state, P-E depends on the transport of moisture from other regions. Part of the impact of the circulation response to warming on P-E can be estimated - assuming linearity - as the change in the moisture transport due to the response in the time-mean winds $(\delta \overline{\mathbf{v}})$ acting on the presentday climatology of moisture $\left(\overline{Q_{p}}\right)$, i.e. $\int-\nabla \cdot\left(\delta \overline{\mathbf{v}} \overline{Q_{p}}\right) d z$. This decomposition is particularly informative where the mean circulation dominates the transport of moisture, e.g. in the tropics [37]. In the mid-latitudes, it can also be important to account for variations in the transport of moisture due to transient atmospheric eddies, such as those populating mid-latitude storm tracks. The transport by transient eddies depends on the daily covariance between wind and moisture anomalies, which makes decomposing this term into a dynamical and thermodynamic contribution substantially more challenging [38]. The same linear decomposition is used to estimate the impact of atmospheric circulation change on precipitation using the energy budget equation [39]. However, the relationship between circulation and hydro-climate is less direct than for the moisture budget, as a change in the transport of dry static energy can be balanced not only by changes in condensational latent heat release, i.e. precipitation, but also by changes in the surface sensibile and radiative heat fluxes.

\section{Regional Climate Models}

Finally, experimental approaches can be used to isolate the relative impacts of atmospheric circulation changes and warming on regional climate. Regional climate models (RCMs) have been particularly useful for this purpose. One such example consists in the so-called "pseudo global warming" experiments [40], in which a warming signal is added to the boundary conditions driving a present-day RCM simulation. By construction, the approach isolates the response of regional climate to warming in the absence of changes in the large-scale atmospheric circulation. This enables to ask how specific past high-impact weather events might have evolved in a warmer climate [41]. In a similar way, the boundary conditions of a RCM can be modified to incorporate only the projected changes in the atmospheric circulation [42]. Further decompositions of the boundary conditions have been proposed in order to isolate the impact of changes in the mean circulation, in the mean static stability and, as a residual, in the transient eddies [43, 444 ]. A possibile limitation is that changes in surface warming, static stability and circulation are physically connected, so that decomposing the boundary conditions in a way that retains meaningful physical balances requires particular care. Nonetheless, the method offers a unique opportunity to directly test how different changes in the atmospheric circulation and warming may determine the response in regional aspects of climate change.

In summary, different methods have different strengths and limitations. No single approach is able to globally and unambiguously define the impact of future circulation changes on regional climate, but confidence can be built by comparing results from different approaches.

\section{Impacts of Circulation Change on Regional Hydro-Climate}

What more could be learnt on regional hydro-climate change if the response of atmospheric circulation were known? On the one hand, soil moisture drought risk is directly increased by warming through a thermodynamic increase in evapotranspiration [45], although partly balanced by the counter-acting effect of enhanced $\mathrm{CO} 2$ on stomatal closure [46]. On the other hand, mid-latitude precipitation, together with river runoff, is strongly controlled by storms and circulation [47]. These aspects will be reviewed in this section, by considering different storylines of circulation change relevant for the precipitation response to warming in three regions with a Mediterranean-like climate: the Mediterranean proper, California and Chile. A comprehensive analysis of hydro-climate variability and change in the 
Mediterranean-like climates from a multi-model mean perspective is given in reference [48].

\section{Winter Mediterranean Circulation Change}

The Mediterranean area has long been identified as a "hotspot" of climate change [49], due to a large projected decline in precipitation, which is of the order of $6 \%$ per degree of global warming in the mean of the CMIP5 model projections [1]. Furthermore, a reduction in Mediterranean precipitation since 1900 is also revealed by reconstructions from rain gauges. This has led many authors to conclude that the projected precipitation decline and increase in meteorological droughts is already happening [50-•53], a finding reported with "medium confidence" in the IPCC 1.5 degrees report [54]. The observed precipitation reduction is largest in the Southern and Eastern Mediterranean in winter. In these areas, the observed precipitation trends largely exceed those projected by the mean of the CMIP5 models [52], possibly because of the influence from internal variability in the atmospheric circulation [•34]. Crucially, these observed trends might already have led to serious societal impacts, such as the case of the 2006-2009 Syrian drought and civil war [55], thus highlighting the vulnerability of the Mediterranean region to hydro-climate variability and change.

Despite this evidence, the real magnitude of the Mediterranean climate change signal is still poorly understood, due to the influence from multi-decadal climate variability $[\bullet 34,56]$, the observational uncertainty in the precipitation reconstructions [50] and the large uncertainty in the magnitude of the projected precipitation decline. However, up to $80 \%$ of the inter-model variance in the precipitation projections is linked to uncertainties in the atmospheric circulation $[57, \cdot 58]$, and this dependence can be used to define distinct storylines of regional climate change. Based on reference [57], Fig. 1a and b compare future projections (2060-2099) of cold season EuroMediterranean precipitation change per degree of global warming evaluated for two subsets of CMIP5 models having, respectively, the least and most negative change in the $850 \mathrm{hPa}$ zonal wind in North Africa, i.e. a simple index for Mediterranean circulation change. A notable anticyclonic circulation anomaly and a larger and more extensive precipitation reduction, i.e. a high-impact storyline for Mediterranean hydro-climate change, is projected in the subset of models responding with a large long-term circulation change (Fig. 1b), while these responses are nearly absent, apart from the East Mediterranean, in the opposite case (Fig. 1a). These differences cannot just be explained by internal variability [57], so that the two storylines reflect different ways in which the atmospheric circulation may respond to warming.
The large precipitation reduction in the high-impact storyline can be confidently attributed to the change in the atmospheric circulation $[50,59,60]$. Associated with the anticyclonic anomaly, climate models project increased atmospheric subsidence and low-level divergence. According to moisture budgets, this mean circulation change is the dominant factor leading to the reduced fresh water availability over land, via increased evaporation and an export of moisture out of the region [59]. At the same time, climate models also project the Mediterranean storm track to become weaker and the number of Mediterranean cyclones to decrease $[61,62]$. This reduced synoptic cyclone activity causes a reduction in the number of rainy days, which only in the Northern Mediterranean region is compensated by a thermodynamically driven increase in the precipitation generated by each storm [62]. Moisture budgets and storm tracking approaches hence provide complementary views on the dependence of Mediterranean drying on circulation change.

A complete dynamical explanation of this localised anticyclonic response and of its driving factors is yet unavailable. The response only weakly projects on the first two modes of Euro-Atlantic atmospheric variability [23], and changes in the structure of the global stationary waves appear to be involved $[15,48]$. Nonetheless, a large circulation response, as in the high-impact storyline (Fig. 1b), tends to be favoured by an amplified warming of the tropical upper troposphere and by a strengthening of the NH stratospheric vortex [•63]. This interpretation is at least qualitatively supported by experiments with atmospheric general circulation models in which the tropical SSTs [50] and the stratospheric vortex $[\bullet 64]$ are perturbed in a controlled manner. Amplified tropical warming is found to be particularly linked to East Mediterranean rainfall $[\bullet 63]$, possibly by inducing a weakening of the Mediterranean storm track, while the stratospheric vortex is mostly linked with Western Mediterranean rainfall, via changes in the position of the North Atlantic storm track $[\bullet 64]$. Interestingly, the projected reduction in Mediterranean precipitation per degree of warming is larger in the mean of the CMIP3 models compared to the more recent CMIP5 models (Fig. 12.41 in reference [1]). Understanding such differences across model generations would be important to test the impact of remote climate responses and circulation biases on Mediterranean climate change.

\section{The Summer NAO and European Rainfall}

If circulation plays an undisputed role on Mediterranean hydro-climate change in the cold season, its role in the warm season is more subtle, and it is here discussed for comparison. 
Fig. 1 Different plausible precipitation and wind at $850 \mathrm{hPa}$ responses to climate change per degree of global warming. Each response is obtained by averaging the 4 CMIP5 models with the most and least positive changes in selected indices of atmospheric circulation. a, b Cold season (NDJFMA) Mediterranean precipitation composites based on the response in the zonal wind at $850 \mathrm{hPa}$ in North Africa $(22.5 \mathrm{~N}-$ $33.5 \mathrm{~N}, 10 \mathrm{~W}-37.5 \mathrm{E}$ ) as defined in [57]. c, d Warm season (MJJASO) European precipitation composites on the magnitude of the poleward shift of the North Atlantic jet (jet latitude defined as in [87] but evaluated for $60 \mathrm{~W}-30 \mathrm{E})$. e, f Cold season California precipitation composites on the mean response in the meridional wind velocity at $300 \mathrm{hPa}$ averaged at the western coast of North America (34 N-48 N, 135 $\mathrm{W}-120 \mathrm{~W}$, roughly box WC in [15]). g, h Annual mean Chilean precipitation response composites on the magnitude of the poleward shift of the SH jet (jet latitude defined as in [87]). The responses are evaluated for 2060-2099 relative to 1960-1999 in the RCP8.5 scenario and scaled by the global warming simulated by each model. Precipitation change (mmday ${ }^{-1} K^{-1}$ ) is shown as shading. The red (blue) lines indicate isotaches of positive (negative) zonal wind responses at $850 \mathrm{hPa}$, with c.i. $0.15,0.3$ and $0.6\left(\mathrm{~ms}^{-1} K^{-1}\right)$. The arrows show the mean wind response at the same level See the Appendix for the list of models included in each composite
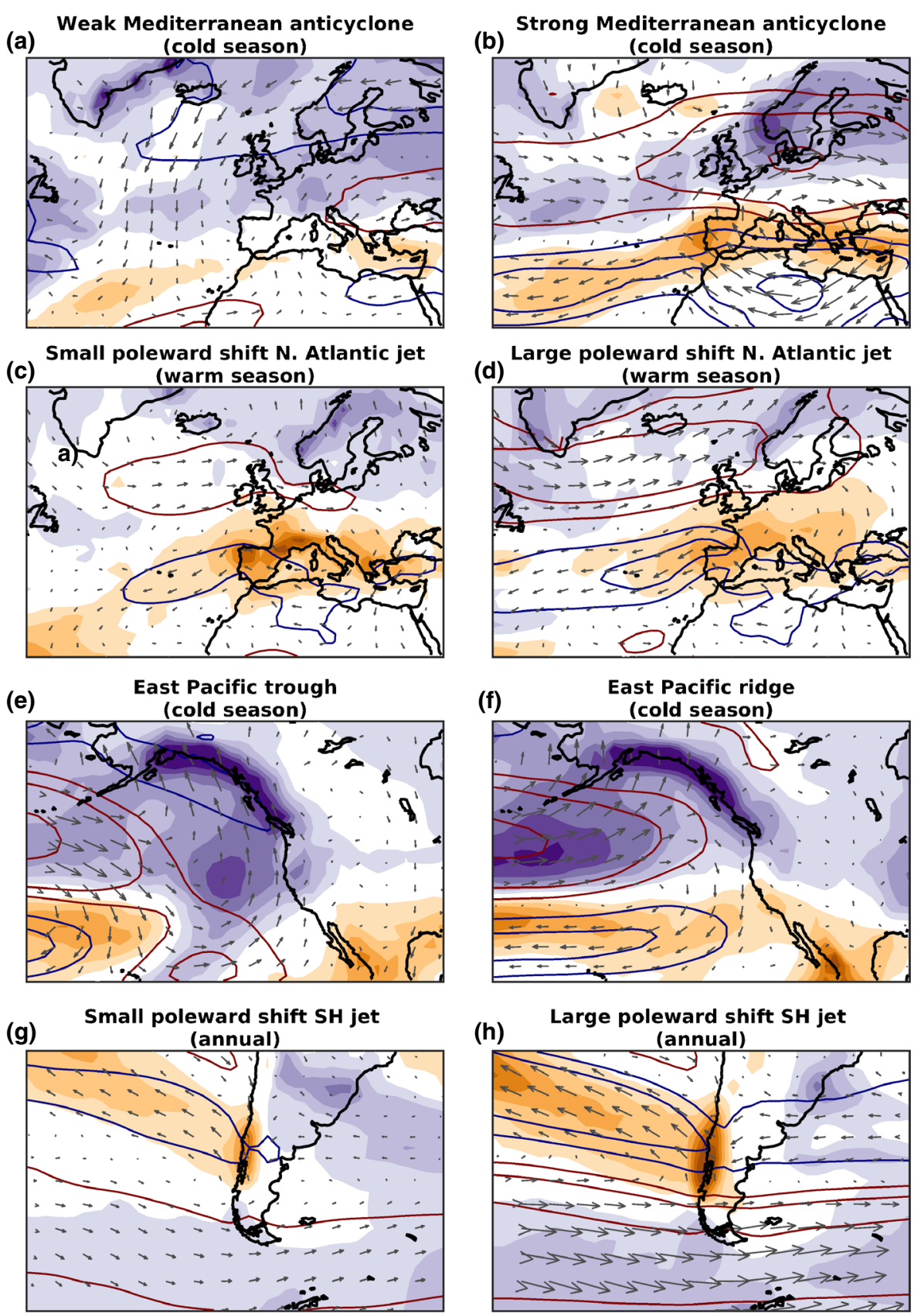

(h)
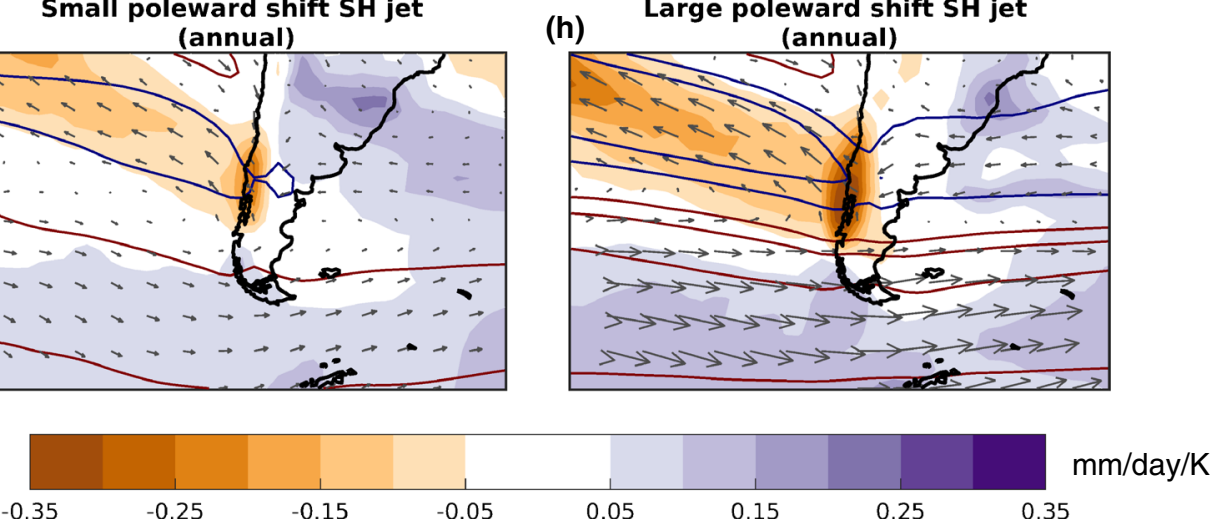

In the warm season, P-E and precipitation are both projected to decline, particularly in Western and Southern Europe [59, 65]. At the same time, the North Atlantic jet is robustly projected to shift poleward as part of a positive trend in the summer North Atlantic Oscillation (SNAO) [21, 65-67]. Analyses of moisture budgets identify the change in the mean atmospheric circulation-particularly the northerly flow linked to the positive SNAO trend - as the dominant contributor to the decline of P-E over most of Europe [59]. However, internal variability analogs [21, 65], and a RCM experiment [42], suggest that only in Northwestern Europe (including UK, Northern France and Northern Germany) more than $50 \%$ of the mean response and inter-model spread in the precipitation change can be attributed to SNAO. Consistent with these findings, the projected precipitation reduction in Southern Europe tends to be comparable in the two 
sets of CMIP5 climate models featuring the smallest and largest poleward shift in the North Atlantic jet (Fig. 1c and d).

These apparently contrasting results can be reconciled in light of the additional warming-mediated processes that contribute to the response of precipitation in the warm season, particularly in Southern Europe [•44]. As the land warms, the soil is projected to become drier, leading to a reduction in evapotranspiration and in the surface relative humidity. These local changes consequently lead to a reduction in clouds and precipitation, which may further enhance the aridity of the soil through an increase in surface shortwave radiation $[42,68]$. Model differences in the representation of moisture feedback and cloud-temperature interactions are responsible for the uncertainty in the magnitude of the precipitation change forced via this mechanism [68]. However, the induced response resembles a suppression of the local hydrological cycle so that, while being important for precipitation, it could have only a negligible impact on P-E. This supports the view that the interaction between circulation, clouds and soil moisture would deserve more investigation [69]. For the purpose of developing storylines, dynamic and thermodynamic driving factors would both need to be accounted for to describe possible future changes in European summer hydro-climate.

The projected positive SNAO trend is partly linked to the projected weakening of the Atlantic Meridional Overturning Circulation (AMOC) [67], and it has not yet emerged in the observations. On the contrary, the observed SNAO trend has been largely negative since the 1990s [70]. Natural decadal variability in the SSTs associated to the Atlantic Multi-decadal Variability (AMV) could in part explain this mismatch [22, 71, 72], but it has also been speculated that the negative SNAO trend could be a forced response to sea ice loss not captured by climate models [70]. As the AMV is now entering a phase reversal [73], new observations will help to evaluate the respective roles played by SST variability and sea ice loss.

\section{The Pacific Jet and California}

California is the only Mediterranean-like climate where the mean of the CMIP5 model projections indicates a slight wetting rather than a large drying [48, 74]. However, the severe multi-year drought of 2011-2016 raised the question of whether the event might have been made more likely by climate change. California precipitation mainly results from winter North Pacific storms tracking eastward towards the US coast [75]. In the drought period, a series of atmospheric ridges formed at the end of the North Pacific storm track, diverting the storms towards higher latitudes $[\bullet 76]$. Most studies agree that while warming is likely to have amplified the soil moisture drought by increasing the evaporative demand $[77,78]$, the anomalous ridge was the result of internal climate variability, although partly forced by an enhanced zonal SST gradient in the tropical Pacific ocean [79-81]. But could a future less rainy California be entirely excluded?

The uncertainty in the precipitation response to climate change in California has been explored in relation to different aspects of atmospheric circulation: the North Pacific subtropical jet $[82,83]$, the North Pacific storm track [75, 84], the location of the subtropical highs [85] and the stationary waves [15]. These different studies have revealed a coherent picture of how different aspects of circulation interact to generate either drier or wetter conditions in the model projections. Inspired by reference [15], two possible storylines are summarised in Fig. 1e and f, where projections of precipitation change per degree of global warming have been conditioned on the long-term response in the meridional wind at $300 \mathrm{hPa}$ at the western coast of North America. One possibility - a best case storyline for California drought (Fig. 1e) - is that the circulation response to warming will be manifested in a strengthening and eastward extension of the subtropical jet towards North America [82]. The strengthening of the subtropical jet would imply more favourable conditions for low-latitude storm development and hence a downstream southward shift in the storm track [84]. It would also induce a lengthening of the stationary wave pattern, which is associated with a shift of the Aleutian low and a stronger southerly flow on the western coast of North America [15]. In this scenario, the shift in the storm-track activity [84] as well as the increased precipitation generated by each storm [75] can be expected to make California more rainy under climate change (Fig. 1e). The alternative storyline (Fig. 1f) is characterised by a poleward shift of the subtropical highs in both the east and the west North Pacific [85]. In this case, a slight ridge would develop on the western coast of North America, leading to a northerly flow anomaly and a drier California. As for the Mediterranean, changes in stationary waves, rather than the zonal-mean Hadley cell expansion, appear to be important for the hydro-climate response in this region [48].

Different hypotheses have been raised on what processes might control these different projections. The extension of the subtropical jet and the trough in the east Pacific resemble the circulation response to $\mathrm{El} \mathrm{Niño,} \mathrm{which}$ would point to the tropical Pacific as a key driver [86]. Consistent with a tropical driving, the southward shift of the jet in the Northeast Pacific only occurs within the slow response to greenhouse forcing, which includes the development of El Niño-like tropical SST anomalies [87]. However, apart from one previous CMIP3 study [88], more recent analyses suggest that the spread in the Northeast Pacific circulation change is linked to uncertainties in the SSTs in the Northwest Pacific, rather than in the tropics $[83,86]$. These extratropical SST anomalies resemble those characterising the Pacific Decadal Oscillation, and their sign is consistent with a surface 
forcing of atmospheric circulation via a modulation of the subtropical vertical wind shear [85]. Alternatively, it may be that the tropical Pacific is an important driver, but its influence in the inter-model spread is obscured by confounding factors arising from the different models' basic states. For example, the influence of biases in the climatology of stationary waves [15] and in the teleconnection of ENSO [89] have been suggested to play a role, although these analyses have reached opposite conclusions on whether an East Pacific trough or ridge is more likely under climate change. Reconciling these two results would be important to increase confidence in future projections of North American hydro-climate.

As a note of caution, the El Niño-like tropical Pacific SST response projected by the models is not yet backed up by the observational record. In contrast, trends in SST reconstructions show muted warming in the eastern tropical Pacific Ocean, thus leading to an enhancement of the zonal tropical Pacific SST gradient [90]. This could be just an expression of internal variability, but some authors note that the El Niño-like response is a "majority decision" in an area where climate models might not represent all relevant processes [90, 91]. If models were systematically wrong, and the forced response was that of an increased zonal SST gradient, California rainfall might follow a different storyline to what current climate models project $[\bullet 76]$.

\section{The SH Jet Shift and Chilean Drought}

In the Southern Hemisphere ( $\mathrm{SH}$ ), the mid-latitude atmospheric circulation response to climate change is to a large extent described as a shift towards the positive phase of the Southern Annular Mode (SAM) [92]. The positive trend in the SAM is observed in the reanalyses in all seasons, with a largest trend in the austral summer due to the additional forcing from ozone depletion in the $\mathrm{SH}$ polar stratosphere $[93,94]$.

The climate impacts due to this forced circulation response can be estimated by considering analogs associated with the observed SAM variability on intra-seasonal and inter-annual timescales. The positive SAM is associated with a poleward shift of the storm track, so that precipitation increases at high-latitudes ( 60S-70S) and decreases in the mid-latitudes $(\sim 40 \mathrm{~S}-50 \mathrm{~S})$ in all seasons [95]. Its impact in the subtropics $(\sim 30 \mathrm{~S})$ has instead a strong seasonality [96]. In the austral winter (JJA), via the shift in the storm track, the positive SAM is associated with subtropical precipitation decrease, a process that has contributed to the observed negative trend in winter rainfall in Southwestern Australia [97]. In the austral summer (DJF), the positive SAM leads instead to precipitation increase in various subtropical land regions [93, 94], via a dynamically induced shift of the descending branch of the Hadley cell [95]. For example, the wetting trend of Eastern South America in the last decades of the twentieth century has been in part attributed to the positive trend in the SAM [98].

A particularly large response from mid-latitude circulation changes is expected to occur in Chile, where the positive SAM leads to year-round dry anomalies shifting from Central (30S$38 \mathrm{~S})$ to Southern $(38 \mathrm{~S}-47 \mathrm{~S})$ Chile with the seasonal cycle [•99]. It is estimated that from 1960 to 2016 rain gauges in Central and Southern Chile have recorded a precipitation reduction of about $2 \%$ and $5 \%$ per decade, respectively [•99]. Despite observational uncertainties being substantial, all datasets show a negative precipitation trend in Central Chile over the past century [48]. The size of these precipitation trends is influenced by a recent multi-year drought, but they are largely congruent with the precipitation response expected from the positive trend in the SAM [100]. ENSO and the Pacific Decadal Oscillation also affect precipitation variability in Chile, but they have only played a minor role on the observed precipitation trend compared to the SAM-related shift in the storm track $[\bullet 99]$.

Based on these results, and since changes in the stationary waves are less important than in the NH [48], developing storylines of regional climate change will require accounting for the response in the latitude and strength of the SH jet and storm tracks. For example, Fig. $1 \mathrm{~g}$ and h compare future projections of annual mean circulation and precipitation change in South America per degree of global warming for the CMIP5 climate models featuring the smallest and largest long-term poleward shift of the $\mathrm{SH}$ jet. Consistent with the expectations from internal variability and moisture budgets [48], the projected Chilean precipitation reduction per degree of warming is larger in the mean of the climate models featuring a large poleward shift in the westerlies (Fig. 1h). This exploratory analysis suggests that quantifying the impact on precipitation due to the uncertainty in the $\mathrm{SH}$ atmospheric circulation response is important to develop storylines of future changes in the frequency of Chilean droughts [101]. The response in the $\mathrm{SH}$ jet could itself be linked to different remote climate responses. In particular, the uncertainty in the jet latitude depends on the magnitude of the polar stratospheric cooling [102, 103] and of the tropical warming, for example, via the response in the cloud cover [104], while the uncertainty in the jet strength has also been linked to the loss of Antarctic sea ice [105]. However, particularly in austral winter, the models with an equatorward bias in the latitude of the $\mathrm{SH}$ jet tend to project a larger poleward shift in response to climate change. This relationship had been suggested as a way to narrow the uncertainty in the future projections, but the argument previously proposed to explain this 
dependence has been shown not to hold [106]. Nonetheless, these findings indicate that it is important to consider ensembles of models with a realistic presentday simulation of the $\mathrm{SH}$ jet to generate plausible storylines of regional climate change in the $\mathrm{SH}$.

\section{Impacts on Windiness: the European Case}

The response of the large-scale atmospheric circulation also has implications for other impact-relevant aspects of extratropical storm tracks. One such aspect is surface windiness associated with intense extratropical cyclones. The mean response of extratropical cyclones to climate change is reviewed in reference [107], within this same section of Current Climate Change Reports. Here, the focus is instead placed on discussing the uncertainty in the response, using future changes in European windiness as a case study.

Central Europe, including the UK and Northern Germany, is vulnerable to wind storm damage due to intense North Atlantic extratropical cyclones [108]. As extratropical cyclones grow on the baroclinicity associated with the midlatitude jet stream [109], intense cyclones are favoured by a strong and zonally extended North Atlantic jet, as found for positive values of the North Atlantic Oscillation (NAO) [110, 111]. Severe European wind storm damage particularly took place in the 1990s, a decade of persistent positive NAO [112], and the possibility of a longer-term GHG-induced upward trend remains open but debated $[108,113]$. In the future projections, climate models indicate a strengthening of the mean westerlies in Central Europe [114]. Several previous studies also reported a future increase in the frequency of moderate to extreme European wind speeds [115-117], with consequences for both wind storm damage [118] and wind energy production $[119, \cdot 120]$, but most analyses of the CMIP5 climate models tend to suggest that these changes are non-robust and often small compared to internal variability [121-124].

Since different remote, regional and mesoscale processes can affect the response of intense North Atlantic extratropical cyclones to climate change, thinking in terms of storylines can be particularly suitable to portray different possible scenarios. On the large-scale, the response of mid-latitude storm tracks is affected by the opposite projected changes in the upper and lower tropospheric meridional temperature gradients $[\bullet 18]$. In the Northeast Atlantic, the impact of the increase in the upper tropospheric temperature gradient tends to win over of the reduction of the lower tropospheric temperature gradient, leading to a net strengthening of the storm track in the multi-model mean [125]. By modulating these temperature gradients, different storylines for the North Atlantic storm track can be considered in relation to the relative magnitude of the tropical upper tropospheric warming, Arctic warming and polar stratospheric cooling - a measure of stratospheric vortex strength $[126,127]$. In particular, the response in the strength of the stratospheric vortex can drive an NAO-like uncertainty in the North Atlantic atmospheric circulation [•64], with possible implications for European windiness $[\bullet 63]$. This is summarised in Fig. 2a and b, where future projections of Euro-Atlantic circulation and windiness change are separately presented for the CMIP5 models (a) Weakening stratospheric vortex

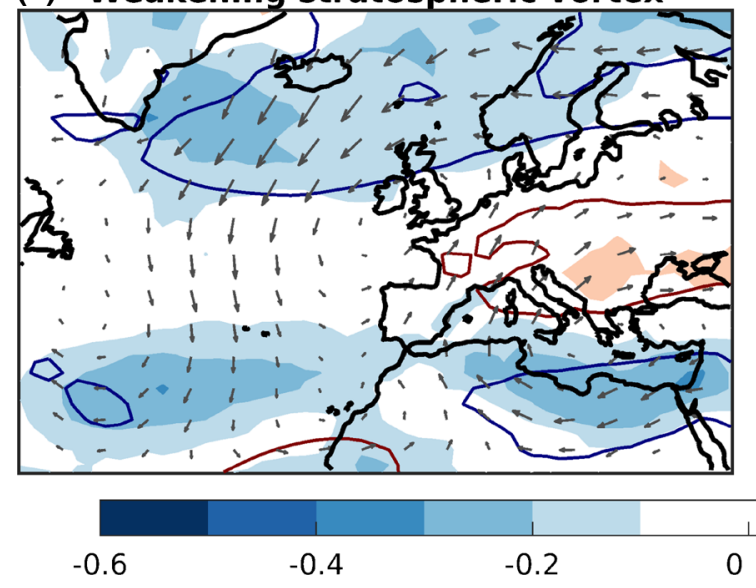

Fig. 2 As in Fig. 1 but for the climate change response in the 98 percentile of the annual distribution of daily wind speed at $850 \mathrm{hPa}$ $\left(\mathrm{ms}{ }^{-1} K^{-1}\right)$ conditioned on the response in the strength of the stratospheric vortex. Each panel shows the average response for the 6 CMIP5 models with the most negative (a) and most positive (b) change in the vortex strength. The vortex strength is evaluated as the zonal-mean

\section{(b) Strengthening stratospheric vortex}

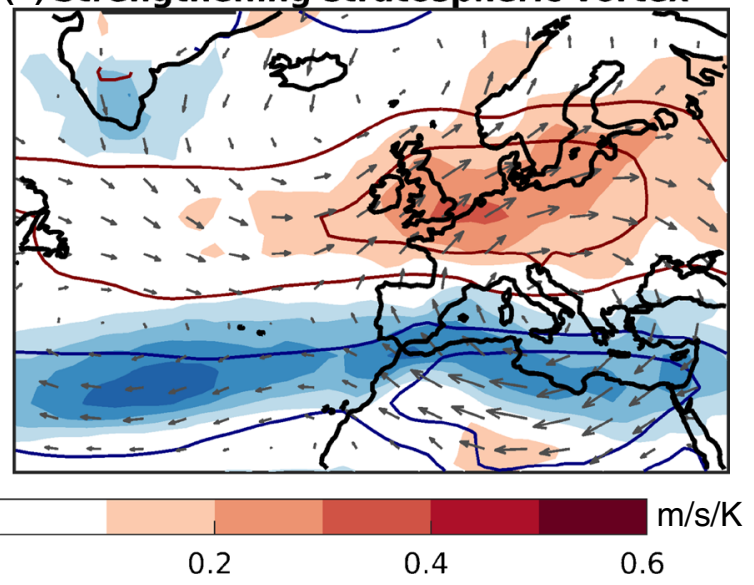

zonal wind at $20 \mathrm{hPa}$ averaged in $60 \mathrm{~N}-75 \mathrm{~N}$ in November-April, as defined in $[\cdot 64]$ apart for the vertical level $(20$ instead of $10 \mathrm{hPa}$, due to larger data availability). Similar results (see $[\bullet 63]$ ) are obtained using the stratospheric vortex index from [126] and the tropospheric NAO index from [149] (not shown). Six models are used in each composite to better sample the noise due to internal variability (see the Appendix for details) 
with a long-term strengthening and weakening of the vortex. Here, windiness is evaluated as the 98 percentile of daily wind speed at $850 \mathrm{hPa}$. An increase in European windiness characterises most models featuring a strengthening of the stratospheric vortex (up to about $1.5 \% / \mathrm{K}$ in Fig. 2b), while it is not found for a weakening of the vortex [ $\bullet 63]$. Additional storylines have been proposed in relation to the relative magnitude of the tropical versus Arctic warming, as "tropically amplified" models tend to be associated with a more squeezed and eastward extended jet into Europe [127]. It seems possible that this response could also favour enhanced European windiness, but it remains to be quantified. Taken together, the relative amplitude of the tropical versus Arctic warming, and the change in the stratospheric vortex strength, show promise to characterise the uncertainty in key aspects of the North Atlantic jet response to climate change, such as its zonal extension and waviness [127].

The attribution of the storm track response to the large-scale drivers discussed above is complicated by the presence of additional changes in surface baroclinicity within the North Atlantic region. In fact, the uncertainty in the North Atlantic storm track response has also been linked to the magnitude of the weakening of the AMOC, which enhances surface baroclinicity at about $50 \mathrm{~N}$ by suppressing the warming of northern North Atlantic SSTs [128]. Supporting this pathway, the strength of the North Atlantic storm track increases in experiments inducing a "collapse" of the AMOC [128, 129] and it covaries with the AMV on multi-decadal timescales [61, 130]. However, climate experiments directly modelling the influence of the projected North Atlantic SST warming patterns provide a less consistent picture: while some studies back up a direct influence on circulation from North Atlantic SSTs $[131,132]$, others only identify a small response [133, 134]. The latter results would suggest that the weakening of the AMOC is largely communicated via a modulation of remote climate responses, such as the ratio between the Arctic and tropical warming [134]. Indeed, tropically amplified models tend to have a stronger North Atlantic SST warming hole [127], thus implying it is difficult to separate these drivers on a statistical basis. Reference [131] discusses possible reasons behind the different experimental results on the response of atmospheric circulation to the North Atlantic SST warming pattern.

Finally, European windiness also depends on additional uncertainties acting on the cyclone scale. For a given atmospheric flow, the thermodynamic increase in the cyclone-associated precipitation is expected to enhance cyclone growth and propagation speed [135], although this pathway is partly balanced by the increase in atmospheric stratification [136]. The impact of enhanced latent heat release on cyclone growth is unlikely to be fully resolved at the spatial resolution of current climate models [137], thus highlighting the value in studies employing high-resolution models to explore the evolution of historical cyclones in a warmer and moister atmosphere [138]. Furthermore, future projections of changes in cyclone-associated wind speeds are systematically more negative at the surface than at $850 \mathrm{hPa}$, both in the $\mathrm{NH}$ and in the $\mathrm{SH}[124,139]$. It has been hypothesised that this might be linked to the vertical profile of the equator-to-pole baroclinicity change [124], but the role of changes in boundary layer processes should perhaps also be quantified [138].

The separation of uncertainties arising from the North Atlantic jet, North Atlantic SSTs and cyclone-associated diabatic process might be questionable, since the jet response is itself influenced by the heat and momentum transport associated with the storm track itself $[\cdot 18]$. Nonetheless, the importance of remote SST warming for the North Atlantic upper tropospheric circulation change [133] suggests there is value in pursuing such an approach. For the purpose of risk assessment, it is the plausibility of high-impact scenarios that is most of interest [140]. Based on the above processes, a worst-case scenario for European windiness change might be expected for a tropically amplified response with a strengthening of the stratospheric vortex, and an enhanced meridional SST gradient in the North Atlantic. Is such a storyline physically self-consistent? and what regional impacts would it exert if realised? Answering these questions could help to place upper bounds on the future change in European wind storm risk.

\section{Conclusions}

Several aspects of regional climate depend on the response of mid-latitude atmospheric circulation to climate change. The hydro-climate response of Mediterraneanlike regions and European windiness downstream of the North Atlantic storm track are high-impact examples that have received recent attention and have been reviewed in this report. While the internal variability in the atmospheric circulation is a leading uncertainty in extratropical regional climate change [141], these examples have served to highlight cases where the uncertainty in the forced circulation response is sufficiently large that the magnitude, and sometimes even the direction, of these regional climate trends cannot yet be anticipated, even for a specified level of global warming (Figs. 1 and 2).

To characterise and communicate this uncertainty, it can be useful to identify different physically self-consistent storylines of how atmospheric circulation and regional climate could 
respond to warming. Crucially, each storyline needs to be enriched by knowledge of the climate aspects that force the respective circulation changes via atmospheric teleconnections $[\cdot 63]$. The relative amplitude of tropical and Arctic warming [50, 104, 134], the response of the AMOC $[67,128,142]$, the patterns of Pacific SST change $[\bullet 76,83,85]$ and changes in stratospheric vortex strength $[\bullet 64,103]$ have here been discussed as possible drivers of the regional climate responses reviewed in this report. Given the uncertainty in these climate responses, the alternative storylines discussed here cannot be discarded and in the present state of knowledge should be considered equally plausible future manifestations of regional climate change.

Having confidence in physical storylines requires nonetheless substantial care. In particular, the response of the atmospheric circulation to the remote climate responses, the absence of confounding influences from the models' biases and the robustness of the storylines across different model generations need to be thoroughly tested. Furthermore, while storylines help to characterise different high-impact future scenarios, they do not immediately enable to reduce the uncertainty in the projections themselves. The analysis of physical relationships between the climate change response and the model biases in the simulation of present-day [143] and past [144, 145] climates is needed for making progress, and potentially deem some storylines implausible.

While recent works have focused on the response of the mean state to climate change, future research should aim to characterise the dependence of the full range of regional climate variability on remote drivers of atmospheric circulation [146, 147]. For example, a recent study based on a single model found that winters with extremely high and low California precipitation could both become more frequent in response to warming due to changes in the amplitude of the year-to-year variability in atmospheric circulation [•148]. Making progress in this direction will necessarily require comparing large initial condition ensembles from different climate models. Producing such datasets will be invaluable for advancing research on regional climate change.

\begin{abstract}
Acknowledgments The author is grateful to Richard Seager and another reviewer for their constructive comments that have helped to improve the manuscript. He also thanks Ted Shepherd for feedback on thr draft of this manuscript and Emanuele Bevacqua and Paulo Ceppi for useful discussions. Finally, he acknowledges the World Climate Research Programme's Working Group on Coupled Modelling and the climate modelling groups for producing and making available the CMIP5 model output. The analysed CMIP5 data is available on the British Atmospheric Data Centre.
\end{abstract}

Funding Information The work is funded by the ERC advanced grant "Understanding the atmospheric circulation response to climate change (ACRCC, grant number 339390)".

\section{Compliance with Ethical Standards}

Conflict of Interest The corresponding author states that there is no conflict of interest.

\section{Appendix: . CMIP5 Models}

Based on their atmospheric circulation response in the RCP8.5 scenario, the following CMIP5 climate models have been identified to produce the panels in Figs. 1 and 2:

- Winter Mediterranean circulation change. Weak anticyclonic response: GISS-E2-H, bcc-csm1-1-m, CMCCCESM, MRI-CGCM3. Strong anticyclonic response: GFDL-CM3, IPSL-CM5A-LR, MIROC-ESM-CHEM, FIO-ESM.

- Summer North Atlantic jet shift. Small poleward shift: GISS-E2-H, GISS-E2-R, IPSL-CM5A-LR, GFDLESM2M. Large poleward shift: ACCESS1-0, GFDLCM3, IPSL-CM5B-LR, CSIRO-Mk3-6-0

- Northeast Pacific. Trough: CNRM-CM5, IPSL-CM5AMR, CSIRO-Mk3-6-0, IPSL-CM5A-LR. Ridge: GFDLESM2M, GISS-E2-R, CMCC-CMS, CMCC-CM

- SH jet. Weak poleward shift: EC-EARTH, CNRM-CM5, CESM1-WACCM, MRI-CGCM3. Large poleward shift: IPSL-CM5A-MR, IPSL-CM5A-LR, CMCC-CMS, MIROC5

- NH stratospheric vortex. Weakening of the vortex: CMCC-CESM, MRI-CGCM3, CMCC-CM, CCSM4, IPSL-CM5A-LR, MPI-ESM-LR. Strengthening of the vortex: GFDL-ESM2G, ACCESS1-3, IPSL-CM5AMR, MIROC5, GFDL-CM3, MIROC-ESM-CHEM

These models have been selected out of a set of 32 CMIP5 models in Fig. 1 and 25 models in Fig. 2, which requires daily data. As discussed in reference [•63], FGOALS-g2 is not considered due to its much larger bias in the North Atlantic jet latitude, although including it would have no impacts on the conclusions. Ensemble member r1ilp1 is analysed for all models, apart for ECEARTH (r2ilp1), CCSM4 (r6ilp1) and CESM-WACCM (r31p1), due to data availability. In Fig. 2, the 98 percentile of daily wind speed is evaluated on the original models' grids. All data is spatially interpolated on a regular 2-degree grid for the purpose of averaging the model responses.

Open Access This article is distributed under the terms of the Creative Commons Attribution 4.0 International License (http:// creativecommons.org/licenses/by/4.0/), which permits unrestricted use, distribution, and reproduction in any medium, provided you give appropriate credit to the original author(s) and the source, provide a link to the Creative Commons license, and indicate if changes were made. 


\section{References}

Papers of particular interest, published recently, have been highlighted as:

- Of importance

- Of major importance

1. Collins M, Knutti R, Arblaster J, Dufrense J, Fichefet T, Friedlingstein P, Gao X, Gutowski WJ, Johns T, Krinner G, Shongwe M, Tebaldi C, Weaver A, Wehner M. In Climate change 2013: the physical science basis. Contribution of Working Group I to the Fifth Assessment Report of the Intergovernmental Panel on Climate Change. In: Stocker T, Qin D, Plattner GK, Tignor M, Allen S, Boschung J, Nauels A, Xia Y, Bex V, and Midgley P, editors. Cambridge: Cambridge University Press; 2013.

2. Yin JH. . Geophys Res Lett 2005;32:1. https://doi.org/10.1029/ 2005 GL023684.

3. Lu J, Vecchi GA, Reichler T. . Geophys Res Lett 2007;34:2. https://doi.org/10.1029/2006GL028443.

4. Finnis J, Holland MM, Serreze MC, Cassano JJ. . J Geophys Res 2007;112:1. https://doi.org/10.1029/2006JG000286.

5. Chang EKM, Guo Y, Xia X. . J Geophys Res 2012;117:1. https:// doi.org/10.1029/2012JD018578.

6. Staten PW, Lu J, Grise KM, Davis SM, Birner T. . Nat Clim Chang 2018;8:768. https://doi.org/10.1038/s41558-018-0246-2.

7. Pfahl S. . Nat Hazards Earth Syst Sci 2014; 14: 1461. https://doi. org/10.5194/nhess-14-1461-2014.

8. Held IM, Soden BJ. . J Clim 2006;19:5686. https://doi.org/10. 1175/JCLI3990.1.

9. Horton DE, Johnson NC, Singh D, Swain DL, Rajaratnam B, Diffenbaugh NS. . Nature 2015; 522:465. https://doi.org/10. 1038/nature14550.

10. Christensen J, Kumar KK, Aldrian E, An SI, Cavalcanti I, de Castro M, Dong W, Goswami P, Hall A, Kanyanga J, Kitoh A, Kossin J, Lau NC, Renwick J, Stephenson D, Xie SP, Zhou T. In Climate change 2013: the physical science basis. Contribution of Working Group I to the Fifth Assessment Report of the Intergovernmental Panel on Climate Change. In: Stocker T, Qin D, Plattner GK, Tignor M, Allen S, Boschung J, Nauels A, Xia Y, Bex V, and Midgley P, editors. Cambridge: Cambridge University Press; 2013.

11. Schmidt DF, Grise KM. . Geophys Res Lett 2017;44(10):573. https://doi.org/10.1002/2017GL075380.

12. Staten PW, Grise KM, Davis SM, Karnauskas K, Davis N. J Geophys Res Atmos. 2019;124. https://doi.org/10.1029/ 2018JD030100.

13. Shepherd T. . Nat Geosci 2014;7:703. https://doi.org/10.1038/ ngeo2253.

14. Knutti R, Furrer R, Tebaldi C, Cermak J, Meehl GA. . J Climate 2010;23:2739. https://doi.org/10.1175/2009JCLI3361.1.

15. Simpson I, Seager R, Ting M, Shaw T. . Nat Clim Chang 2016;6: 65. https://doi.org/10.1038/nclimate2783.

16. van den Hurk B, Siegmund P, Klein Tank A, Attema J, Bakker A, Beersma J, Bessembinder J, Boers R, Brandsma T, Brink HVD, Drijfhout S, Eskes H, Haarsma R, Hazeleger W, Jilderda R, Katsman C, Lenderink G, Loriaux J, Meijgaard EV, Noije TV, Oldenborgh GJV, Selten F, Siebesma P, Sterl A, Vries HD, van Weele M, de Winter R, van Zadelhoff G, KNMI. 2014. KNMI'14: Climate change scenarios for the 21st century - a Netherlands perspective. Technical Report.

17. Shepherd T, Boyd E, Calel RA, Chapman SC, Dessai S, DimaWest IM, Fowler HJ, James R, Maraun D, Martius O, Senior CA, Sobel AH, Stainforth DA, Tett SF, Trenberth KE, van den Hurk BJ, Watkins NW, Wilby RL, Zenghelis DA. . Clim Chang
2018;151: 555. https://doi.org/10.1007/s10584-018-2317-9. A comprehensive description of the concept and use of storylines to discuss uncertainty in climate change projections.

18. Shaw T, Baldwin M, Barnes EA, Caballero R, Garfinkel CI, Hwang YT, Li C, O'Gorman PA, Rivière G, Simpson I, Voigt A. . Nat Geosci 2016;9:656. https://doi.org/10.1038/ngeo2783. A comprehensive review on the processes shaping midlatitude circulation change.

19. Deser C, Phillips A, Alexander MA, Smoliak BV. . J Climate 2014; 27: 2271. https://doi.org/10.1175/JCLI-D-13-00451.1.

20. Deser C, Magnusdottir G, Saravanan R, Phillips A. . J Clim 2004; 17:877.

21. Bladé I, Fortuny D, Van Oldenborgh GJ, Liebmann B. . J Geophys Res 2012;117:D16104. https://doi.org/10.1029/2012JD017816.

22. Deser C, Hurrell JW, Phillips A. . Clim Dyn 2017;49:3141. https:// doi.org/10.1007/s00382-016-3502-Z.

23. Gonzalez P, Brayshaw DJ, Zappa G. 2019. Clim Dyn In press. https://doi.org/10.1007/s00382-019-04776-3.

24. Cassano JJ, Uotila P, Lynch AH, Cassano EN. . J Geophys Res 2007;112:G04S49. https://doi.org/10.1029/2006JG000332.

25. Santos J, Belo-Pereira M, Fraga H, Pinto J. . J Geophys Res Atmos 2016;121:1170. https://doi.org/10.1002/2015JD024399.

26. Gibson PB, Perkins-Kirkpatrick SE, Renwick JA. . Int J Climatol 2016;36:3934. https://doi.org/10.1002/joc.4604.

27. Amini S, Straus DM. 2019. Clim Dyn In press. https://doi.org/10. 1007/s00382-018-4409-7.

28. Saffioti C, Fischer E, Knutti R. . J Clim 2017;30:7271. https://doi. org/10.1175/JCLI-D-16-0695.1.

29. Ullmann A, Fontaine B, Roucou P. . Int J Climatol 2014;34:2634 https://doi.org/10.1002/joc.3864.

30. Deser C, Terray L, Phillips A. . J Clim 2016;29:2237. https://doi. org/10.1175/JCLI-D-15-0304.1. A useful and clear decomposition of the climate change response into dynamic and thermodynamic components using constructed circulation analogs.

31. Lehner F, Deser C, Terray L. . J Clim 2017;30:7739. https://doi. org/10.1175/JCLI-D-16-0792.1.

32. Smoliak BV, Wallace JM, Lin P, Fu Q. . J Clim 2015;28:1613. https://doi.org/10.1175/JCLI-D-14-00111.1.

33. Lehner F, Deser C, Simpson I, Terray L. . Geophys Res Lett 2018;45(12):6251. https://doi.org/10.1029/2018GL078312.

34. - Guo R, Deser C, Terray L, Lehner F. . Geophys Res Lett 2019;46: 3426. https://doi.org/10.1029/2018GL081316. First application of dynamical adjustment to highlight the agreement between observed and modelled precipitation trends in the past century.

35. Seager R, Vecchi GA. . Proc Natl Acad Sci 2010;107:21227. https://doi.org/10.1073/pnas.0910856107.

36. Muller CJ, O'Gorman PA. . Nat Clim Chang 2011;1:266. https:// doi.org/10.1038/nclimate1169.

37. Chadwick R, Boutle I, Martin G. . J Clim 2013;26:3803. https:// doi.org/10.1175/JCLI-D-12-00543.1.

38. Byrne MP, O'Gorman PA. . J Clim 2015;28:8078. https://doi.org/ 10.1175/JCLI-D-15-0369.1.

39. Richardson TB, Forster PM, Andrews T, Parker DJ. . J Clim 2016; 29: 583. https://doi.org/10.1175/JCLI-D-15-0174.1.

40. Schär C, Frei C, Lüthi D, Davies HC. . Geophys Res Lett 1996; 23: 669. https://doi.org/10.1029/96GL00265.

41. Meredith EP, Semenov VA, Maraun D, Park W, Chernokulsky AV. . Nat Geosci 2015;8:615. https://doi.org/10.1038/ngeo2483.

42. Rowell DP, Jones RG. . Clim Dyn 2006;27:281. https://doi.org/10. 1007/s00382-006-0125-9.

43. Kröner N, Kotlarski S, Fischer E, Lủthi D, Zubler E, Schär C. Clim Dyn 2017;48:3425. https://doi.org/10.1007/s00382-0163276-3. 
44. Brogli R, Kroner N, Sorland S, Luthi D, Schar C. . J Clim 2019;32:385. https://doi.org/10.1175/JCLI-D-18-0431.1. A novel RCM approach to disentangling different driving factors of summer European temperature and precipation change.

45. Samaniego L, Thober S, Kumar R, Wanders N, Rakovec O, Pan M, Zink M, Sheffield J, Wood EF, Marx A. . Nat Clim Chang 2018;8:421. https://doi.org/10.1038/s41558-018-0138-5.

46. Scheff J. . Curr Clim Chang Rep 2018;4:202. https://doi.org/10. 1007/s40641-018-0094-1.

47. Hawcroft MK, Shaffrey L, Hodges K, Dacre HF. . Geophys Res Lett 2012;39:L24809. https://doi.org/10.1029/2012GL053866.

48. Seager R, Osborn T, Kushnir Y, Simpson I, Nakamura J, Liu H. . J Clim 2019;32:2887. https://doi.org/10.1175/JCLI-D-18-0472.1.

49. Giorgi F. . Geophys Res Lett 2006;33:L08707. https://doi.org/10. 1029/2006GL025734.

50. Hoerling M, Eischeid J, Perlwitz J, Quan X, Zhang T, Pegion P. . J Clim 2012;25:2146. https://doi.org/10.1175/JCLI-D-11-00296.1.

51. Kelley C, Ting M, Seager R, Kushnir Y. . Geophys Res Lett 2012;39:1. https://doi.org/10.1029/2012GL053416.

52. Mariotti A, Pan Y, Zeng N, Alessandri A. . Clim Dyn 2015;44: 1437. https://doi.org/10.1007/s00382-015-2487-3.

53. Gudmundsson L, Seneviratne S. . Environ Res Lett 2016;11: 044005. https://doi.org/10.1088/1748-9326/11/4/044005. Latest study indicating that climate change is likely to have increased the frequency of droughts in Southern Europe.

54. Hoegh-Guldberg O, Jacob D, Taylor M, Bindi M, Brown S, Camilloni I, Diedhiou A, Djalante R, Ebi K, Engelbrecht F, Guiot J, Hijioka Y, Mehrotra S, Payne A, Seneviratne S, Thomas A, Warren R, Zhou G. In Global Warming of $1.5,{ }^{\circ} \mathrm{c}$. An IPCC Special Report on the impacts of global warming of $1.5,{ }^{\circ} \mathrm{C}$ above pre-industrial levels and related global greenhouse gas emission pathways, in the context of strengthening the global response to the threat of climate change. In Press. In: MassonDelmotte V, Zhai P, Pórtner HO, Roberts D, Skea J, Shukla P, Pirani A, Moufouma-Okia W, Péan C, Pidcock R, Connors S, Matthews J, Chen Y, Zhou X, Gomis M, Lonnoy E, Maycock T, Tignor M, and Waterfield T, editors; 2018, https://doi.org/10. 1002/ejoc.201200111.

55. Kelley C, Mohtadi S, Cane M, Seager R, Kushnir Y. . Proc Natl Acad Sci 2015;112:3241. https://doi.org/10.1073/pnas. 1421533112

56. Mariotti A, Dell'Aquila A. . Clim Dyn 2012;38:1129. https://doi. org/10.1007/s00382-011-1056-7.

57. Zappa G, Hoskins BJ, Shepherd T. . Environ Res Lett 2015;10: 104012. https://doi.org/10.1088/1748-9326/10/10/104012.

58. Fereday D, Chadwick R, Knight J, Scaife AA. . J Clim 2018;31: 963. https://doi.org/10.1175/JCLI-D-17-0048.1. An original application of weather analogs to quantify the importance of atmospheric circulation change for the uncertainty in European precipitation projections.

59. Seager R, Liu H, Henderson N, Simpson I, Kelley C, Shaw T, Kushnir Y, Ting M. . J Clim 2014;27:4655. https://doi.org/10. 1175/JCLI-D-13-00446.1.

60. Li C, Michel C, Seland Graff L, Bethke I, Zappa G, Bracegirdle T, Fischer E, Harvey B, Iversen T, King M, Krishnan H, Lierhammer L, Mitchell D, Scinocca J, Shiogama H, Stone D, Wettstein J. . Earth Syst Dynam 2018;9:359. https://doi.org/10.5194/esd-9-3592018.

61. Nissen KM, Ulbrich U, Leckebusch GC, Kuhnel I. . Clim Dyn 2014; 43: 1545. https://doi.org/10.1007/s00382-013-1975-6.

62. Zappa G, Hawcroft MK, Shaffrey L, Black E, Brayshaw DJ. . Clim Dyn 2014;45:1727. https://doi.org/10.1007/s00382-0142426-8.

63. Zappa G, Shepherd T. . J Clim 2017;30:6561. https://doi.org/10. 1175/JCLI-D-16-0807.1. An example of storyline approach applied to characterise European climate change conditionally on different remote drivers of atmospheric circulation change.

64. Simpson I, Hitchcock P, Seager R, Wu Y, Callaghan P. . J Clim 2018;31:6371. https://doi.org/10.1175/JCLI-D-18-0041.1. First experimental evidence that uncertainties in the response to climate change in the strength of the NH stratospheric vortex can influence European circulation and hydroclimate.

65. Boé J, Terray L, Cassou C, Najac J. . Clim Dyn 2009;33:265. https://doi.org/10.1007/s00382-008-0474-7.

66. Barnes EA, Polvani L. . J Clim 2013;26:7117. https://doi.org/10. 1175/JCLI-D-12-00536.1.

67. Haarsma RJ, Selten F, Drijfhout SS. . Environ. Res. Lett 2015;10: 094007.

68. Boé J, Terray L. . Clim Dyn 2014;42:683. https://doi.org/10.1007/ s00382-013-1868-8.

69. Haren RV, Haarsma RJ, Vries HD, Oldenborgh GJV, Hazeleger W. Environ Res Lett 2015; 10:055002. https://doi.org/10.1088/ 1748-9326/10/5/055002.

70. Hanna E, Cropper TE, Jones PD, Scaife AA, Allan R. . Int J Climatol 2015;35:2540. https://doi.org/10.1002/joc.4157.

71. Sutton R, Dong B. . Nat Geosci 2012;5:788. https://doi.org/10. 1038/ngeo1595.

72. Dong B, Sutton R, Woollings T, Hodges K. . Environ Res Lett 2013;8:034037. https://doi.org/10.1088/1748-9326/8/3/034037.

73. Robson J, Ortega P, Sutton R. . Nat Geosci 2016;9:513. https://doi. org/10.1038/ngeo2727.

74. Polade SD, Gershunov A, Cayan DR, Dettinger MD, Pierce DW. Sci Rep 2017;7:10783. https://doi.org/10.1038/s41598-01711285-y.

75. Osburn L, Keay K, Catto J. . J Clim 2018;31:3451. https://doi.org/ 10.1175/JCLI-D-17-0556.1.

76. Seager R, Henderson N, Cane M, Liu H, Nakamura J. . J Clim 2017;30:10237. https://doi.org/10.1175/JCLI-D-17-0192.1. A critical discussion of whether anthropogenic warming is responsible for increasing drought in California obtained by combining model projections and observational evidence.

77. Diffenbaugh NS, Swain DL, Touma D. . Proc Natl Acad Sci 2015;112:3931. https://doi.org/10.1073/pnas.1422385112.

78. Williams A, Seager R, Abatzoglou J, Cook B, Smerdon J, Cook E. . Geophys Res Lett 2015; 42:1. https://doi.org/10.1002/ 2015GL064924.Received.

79. Palmer T. . Science 2014;344:803. https://doi.org/10.1126/ science. 1255147.

80. Hartmann DL. . Geophys Res Lett 2015;42:1894. https://doi.org/ 10.1002/2015GL063083.

81. Seager R, Hoerling M, Schubert S, Wang H, Lyon B, Kumar A, Nakamura J, Henderson N. . J Clim 2015;28:6997. https://doi.org/ 10.1175/JCLI-D-14-00860.1.

82. Neelin JD, Langenbrunner B, Meyerson JE, Hall A, Berg N. . J Clim 2013;26:6238. https://doi.org/10.1175/JCLI-D-12-00514.1.

83. Langenbrunner B, Neelin JD, Lintner BR, Anderson BT. . J Clim 2015;28:7857. https://doi.org/10.1175/JCLI-D-14-00800.1.

84. Chang EKM, Zheng C, Lanigan P, Yau AMW, Neelin JD. Geophys Res Lett 2015;42:5983. https://doi.org/10.1002/ 2015GL064424.

85. Choi J, Lu J, Son S, Frierson DMW, Yoon JH. . J Geophys Res Atmos 2016;121:795. https://doi.org/10.1002/2015JD023858.

86. Allen RJ, Luptowitz R. . Nat Commun 2017;8:1. https://doi.org/ 10.1038/ncomms16055.

87. Ceppi P, Zappa G, Shepherd T, Gregory JM. . J Clim 2018;31: 1091. https://doi.org/10.1175/JCLI-D-17-0323.1.

88. Delcambre SC, Lorenz DJ, Vimont DJ, Martin JE. . J Clim 2013; 26: 4930. https://doi.org/10.1175/JCLI-D-12-00359.1.

89. Allen RJ, Anderson RG. . npj Clim Atmosph Sci 2018;1:21. https://doi.org/10.1038/s41612-018-0032-x. 
90. Seager R, Cane M, Henderson N, Lee DE, Abernathey R, Zhang H. . Nat Clim Chang 2019; 9:517. https://doi.org/10.1038/s41558019-0505-x.

91. Kohyama T, Hartmann DL. . J Clim 2017;30:4227. https://doi.org/ 10.1175/JCLI-D-16-0541.1.

92. Kushner PJ, Held IM, Delworth TL. . J Clim 2001;14:2238. https://doi.org/10.1175/1520-0442(2001)014<0001:SHACRT>2. $0 . \mathrm{CO} ; 2$.

93. Thompson D, Solomon S, Kushner PJ, England MH, Grise KM, Karoly DJ. . Nat Geosci 2011;4:741. https://doi.org/10.1038/ ngeo1296.

94. Lee S, Feldstein SB. . Science 2011;339:563.

95. Hendon HH, Lim EP, Nguyen H. . J Clim 2014;27:3446. https:// doi.org/10.1175/JCLI-D-13-00550.1.

96. Lim EP, Hendon HH, Arblaster JM, Delage F, Nguyen H, Min SK, Wheeler MC. . Geophys Res Lett 2016;43:7160. https://doi.org/ 10.1002/2016GL069453.

97. Delworth TL, Zeng F. . Nat Geosci 2014;7:583. https://doi.org/10. 1038/ngeo2201.

98. Gonzalez PL, Polvani LM, Seager R, Correa GJ. . Clim Dyn 2014; 42: 1775. https://doi.org/10.1007/s00382-013-1777-x.

99. Boisier JP, Alvarez-Garretón C, Cordero RR, Damiani A, Gallardo L, Garreaud RD, Lambert F, Ramallo C, Rojas M, Rondanelli R. . Elem Sci Anth 2018;6:74. https://doi.org/10. 1525/elementa.328. A thorough assessment of climate change in Chile, highlighting the importance of anthropogenically forced circulation changes for the recent increase in the frequency in Chilean drought.

100. Boisier JP, Rondanelli R, Garreaud RD, Muñoz F. . Geophys Res Lett 2016;43:413. https://doi.org/10.1002/2015GL067265.

101. Bozkurt D, Rojas M, Boisier JP, Valdivieso J. . Clim Chang 2018; 150: 131. https://doi.org/10.1007/s10584-018-2246-7.

102. Wenzel S, Eyring V, Gerber E, Karpechko AY. . J Climate 2016;29:673. https://doi.org/10.1175/JCLI-D-15-0412.1.

103. Ceppi P, Shepherd T. Geophys Res Lett. 2019;46. https://doi.org/ 10.1029/2019GL082883.

104. Ceppi P, Zelinka MD, Hartmann DL. . Geophys Res Lett 2014; 41: 3244. https://doi.org/10.1002/2014GL060043.

105. Bracegirdle TJ, Hyder P, Holmes CR. . J Clim 2018;31:195. https://doi.org/10.1175/JCLI-D-17-0320.1.

106. Simpson I, Polvani LM. . Geophys Res Lett 2016;43:2896. https:// doi.org/10.1002/2016GL067989.

107. Catto J, Ackerley D, Booth J, Champion A, Colle B, Phahl S, Pinto J, Quinting J, Seiler C. 2019. Curr Clim Change Rep In Press.

108. Feser F, Barcikowska M, Krueger O, Schenk F, Weisse R, Xia L. . QJ R Meteorol Soc 2015; 141:350. https://doi.org/10.1002/qj. 2364.

109. Hoskins BJ, Valdes PJ. . J Atmos Sci 1990;47:1854. https://doi. org/10.1175/1520-0469(1990)047<1854:OTEOST>2.0.CO;2.

110. Donat MG, Leckebusch GC, Pinto JG, Ulbrich U. . Int J Climatol 2010;30:1289. https://doi.org/10.1002/joc. 1982.

111. Zubiate L, McDermott F, Sweeney C, O’Malley M. . QJ R Meteorol Soc 2017;143:552. https://doi.org/10.1002/qj.2943.

112. Dawkins LC, Stephenson DB, Lockwood JF, Maisey PE. . Nat Hazards Earth Syst Sci 2016;16: 1999. https://doi.org/10.5194/ nhess-16-1999-2016.

113. Gregow H, Laaksonen A, Alper ME. . Sci Rep 2017;7:1. https:// doi.org/10.1038/srep46397.

114. Simpson I, Shaw T, Seager R. . J Atmos Sci 2014;71:2489. https:// doi.org/10.1175/JAS-D-13-0325.1.

115. Gastineau G, Soden BJ. . Geophys Res Lett 2009;36:1. https://doi. org/10.1029/2009GL037500.

116. Donat MG, Leckebusch GC, Wild S, Ulbrich U. . Nat Hazards Earth Syst Sci 2011;11:1351. https://doi.org/10.5194/nhess-111351-2011.
117. Pryor SC, Barthelmie RJ, Clausen NE, Drews M, MacKellar N, Kjellstróm E. . Clim Dyn 2012;38:189. https://doi.org/10.1007/ s00382-010-0955-3.

118. Schwierz C, Köllner-Heck P, Mutter EZ, Bresch DN, Vidale PL, Wild M, Schär C. . Clim Chang 2010;101:485. https://doi.org/10. 1007/s10584-009-9712-1.

119. Tobin I, Vautard R, Balog I, Brèon FM, Jerez S, Ruti PM, Thais F, Vrac M, Yiou P. . Clim Chang 2015;128:99. https://doi.org/10. 1007/s10584-014-1291-0.

120. Reyers M, Moemken J, Pinto JG. . Int J Climatol 2016;36:783. https://doi.org/10.1002/joc.4382. An original combination of circulation anologs and regional downscaling to infer the surface wind-climate response to future changes in the large-scale atmospheric circulation.

121. De Winter RC, Sterl A, Ruessink BG. . J Geophys Res Atmos 2013;118:1601. https://doi.org/10.1002/jgrd.50147.

122. Kumar D, Mishra V, Ganguly AR. . Clim Dyn 2015;45:441. https://doi.org/10.1007/s00382-014-2306-2.

123. Seiler C, Zwiers FW. . Clim Dyn 2016;46:3633. https://doi.org/10. 1007/s00382-015-2791-y.

124. Chang EKM. . J Clim 2018;31:6527. https://doi.org/10.1175/ JCLI-D-17-0899.1.

125. Harvey BJ, Shaffrey L, Woollings T. . Clim Dyn 2014;43:1171. https://doi.org/10.1007/s00382-013-1883-9.

126. Manzini E, Karpechko AY, Anstey J, Baldwin MP, Black RX, Cagnazzo C, Calvo N, Christiansen B, Davini P, Gerber E, Giorgetta M, Gray L, Hardiman SC, Lee Y, Marsh DR, Mcdaniel BA, Purich A, Scaife AA, Shindell D, Son S, Watanabe S, Zappa G. J Geophys Res Atmos. 2014;119. https:// doi.org/10.1002/2013JD021403.

127. Peings Y, Cattiaux J, Vavrus SJ, Magnusdottir G. . Environ Res Lett 2018;13:074016. https://doi.org/10.1088/1748-9326/aacc79.

128. Woollings T, Gregory JM, Pinto JG, Reyers M, Brayshaw DJ. . Nat Geosci 2012;5:313. https://doi.org/10.1038/ngeo1438.

129. Jackson LC, Kahana R, Graham T, Ringer MA, Woollings T, Mecking JV, Wood RA. . Clim Dyn 2015;45:3299. https://doi. org/10.1007/s00382-015-2540-2.

130. Zhang R, Sutton R, Danabasoglu G, Kwon YO, Marsh R, Yeager SG, Amrhein DE, Little CM. 2019. Rev Geophys 1-60. https:// doi.org/10.1029/2019RG000644.

131. Gervais M, Shaman J, Kushnir Y. . J Clim 2019;32:2673. https:// doi.org/10.1175/JCLI-D-18-0647.1.

132. Hand R, Keenlyside NS, Omrani N, Bader J, Greatbatch R. Clim Dyn in press. 2019. https://doi.org/10.1007/s00382-018-4151-1.

133. Ciasto LM, Li C, Wettstein JJ, Kvamstø NG. . J Clim 2016;29: 6973. https://doi.org/10.1175/JCLI-D-15-0860.1.

134. Harvey BJ, Shaffrey L, Woollings T. . Clim Dyn 2015;45:2847. https://doi.org/10.1007/s00382-015-2510-8.

135. Tamarin-Brodsky T, Kaspi Y. . Nat Geosci 2017;10:908. https:// doi.org/10.1038/s41561-017-0001-8.

136. Pfahl S, O’Gorman PA, Singh MS. . J Clim 2015;28:9373. https:// doi.org/10.1175/JCLI-D-14-00816.1.

137. Willison J, Robinson WA, Lackmann GM. . J Clim 2015;28:4513. https://doi.org/10.1175/JCLI-D-14-00715.1.

138. Vautard R, Jan Van Oldenborgh G, Otto FE, Yiou P, De Vries H, Van Meijgaard E, Stepek A, Soubeyroux JM, Philip S, Kew SF, Costella C, Singh R, Tebaldi C. . Earth Syst Dyn 2019; 10:271. https://doi.org/10.5194/esd-10-271-2019.

139. Chang EK. . J Clim 2017;30:4915. https://doi.org/10.1175/JCLID-16-0553.1.

140. Sutton R. . Earth Syst Dyn 2018;9:1155. https://doi.org/10.5194/ esd-9-1155-2018.

141. Xie SP, Deser C, Vecchi GA, Collins M, Delworth TL, Hall A, Hawkins E, Johnson NC, Cassou C, Giannini A, Watanabe M. . Nat Clim Chang 2015;5:921. https://doi.org/10.1038/ nclimate2689. 
142. Haarsma RJ, Selten F, Oldenborgh GJV. . Clim Dyn 2013;41: 2577. https://doi.org/10.1007/s00382-013-1734-8.

143. Hall A, Cox P, Huntingford C, Klein S. . Nat Clim Chang 2019;9: 269. https://doi.org/10.1038/s41558-019-0436-6.

144. Schmidt GA, Annan JD, Bartlein PJ, Cook BI, Guilyardi E, Hargreaves JC, Harrison SP, Kageyama M, Legrande AN, Konecky B, Lovejoy S, Mann ME, Masson-Delmotte V, Risi C, Thompson D, Timmermann A, Yiou P. . Clim Past 2014;10:221. https://doi.org/10.5194/cp-10-221-2014.

145. Burls NJ, Fedorov AV. . Proc Natl Acad Sci 2017;114:12888. https://doi.org/10.1073/pnas.1703421114.

146. Sexton DMH, Harris GR. . Nat Clim Chang 2015;5:931. https:// doi.org/10.1038/NCLIMATE2705.
147. Berg N, Hall A. . J Clim 2015;26:6324. https://doi.org/10.1175/ JCLI-D-14-00624.1.

148. Swain DL, Langenbrunner B, Neelin JD, Hall A. . Nat Clim Chang 2018;8:427. https://doi.org/10.1038/s41558-018-0140-y. A convicing case about the need for large initial condition ensembles to identify climate impacts associated with changes in the year-to-year atmospheric variability.

149. Gillett NP, Fyfe JC. . Geophys Res Lett 2013;40:1189. https://doi. org/10.1002/grl.50249.

Publisher's Note Springer Nature remains neutral with regard to jurisdictional claims in published maps and institutional affiliations. 